\title{
The role of innovative ideas in business sustainability: Evidence from textile industry
}

\author{
Sasiwimon Wongwilai ${ }^{*}$, Pongtep Phudetch ${ }^{\mathrm{a}}$, Pitiphoj Saelek ${ }^{\mathrm{a}}$, Aekachai Khuptawatin ${ }^{\mathrm{b}}$, Kitichai \\ Wongcharoensin $^{\mathrm{c}}$, Sarawut Chaitongrat ${ }^{\mathrm{c}}$, Ronnakorn Vaiyavuth ${ }^{\mathrm{d}}$ and Kittisak Jermsittiparsert $\mathrm{t}^{\mathrm{e}, \mathrm{f}, \mathrm{g}}$
}

${ }^{a}$ College of Logistics and Supply Chain, Suan Sunandha Rajabhat University, Thailand

${ }^{b}$ Faculty of Business Administration and Information Technology, Rajamangala University of Technology Isan, Thailand

${ }^{c}$ CPL Group Public Company Limited, Thailand

${ }^{d}$ Chulalongkorn School of Integrated Innovation, Chulalongkorn University, Thailand

eUniversitas Muhammadiyah Makassar, Indonesia

${ }^{f}$ College of Innovative Business and Accountancy, Dhurakij Pundit University, Thailand

${ }^{g}$ Faculty of Social and Political Sciences, Universitas Muhammadiyah Sinjai, Indonesia

${ }^{h}$ Faculty of Social and Political Sciences, Universitas Muhammadiyah Makassar, Indonesia

\section{H R O N I C L E}

Article history:

Received September 18, 2020

Received in revised format May 8, 2021

Accepted August 282021

Available online

August 282021

Keywords:

Innovative Ideas

Innovative Process

Innovative Production

Innovative Supply Chain

Business Sustainability

Textile Industry

\section{A B S T R A C T}

The objective of the current study was to examine the role of innovative ideas in business sustainability. The mediating role of innovative process, innovative production and innovative supply chain was also examined. Therefore, the relationship between innovative ideas, innovative process, innovative production, innovative supply chain and business sustainability was examined. Data was collected from the employees of textile companies. As the Indonesian textile companies were under investigation in the current study. Data was collected from Indonesian textile company employees. 300 questionnaires were sent to the textile companies with the help of email. Hence, email surveys were preferred with the help of questionnaires. Results of the study highlights that the innovative ideas had a major role in business sustainability. Introduction of new ideas inside the boundaries of the organization expedites the business sustainability. Additionally, innovative ideas have a positive effect on innovative production and innovative supply chains. Moreover, innovative production and innovative supply chain have a positive effect on business sustainability. Therefore, innovative ideas increase the innovative production and supply chain which further shows a positive effect on business sustainability.

\section{Introduction}

Business sustainability has a vital role among the organizations as the sustainability in the business has a major role in the firm's success (Jermsittiparsert, 2020, 2021). Sustainable business always leads to higher business performance, however, low level of sustainability in the business has a negative role in business. Sustainability means the consistency in the performance of business. A business must have sustainable business in the market, otherwise the competitors may capture the market share which causes the performance to decrease. Therefore, sustainability in the business has importance in the current business market (Rossi, Bertassini, dos Santos Ferreira, do Amaral, \& Ometto, 2020). The current study is based on the business sustainability in the textile sector of Indonesia. Textile sector of Indonesia has vital potential in the textile market; however, the performance of the Indonesian textile sector is not sustainable. This sector of Indonesia is lacking with the level of sustainability which is showing a negative role on business activities. Better performance of this sector requires a significant level of business sustainability (Bellucci, Bini, \& Giunta, 2020). Indonesia's textile as well as garment industry enjoyed significant growth through 2019 with exports having value achieved at US\$13.8 billion, an upsurge from US\$10 billion in 2018 as well as making the country the largest textile manufacturer in the world. The exports of the Indonesian textile sector are shown in Fig. 1.

* Corresponding author

E-mail address: $\underline{\text { sasiwimom.wo@ssru.ac.th }}$ (S. Wongwilai)

(C) 2022 Growing Science Ltd. All rights reserved.

doi: $10.5267 /$ j.uscm.2021.8.011 
8

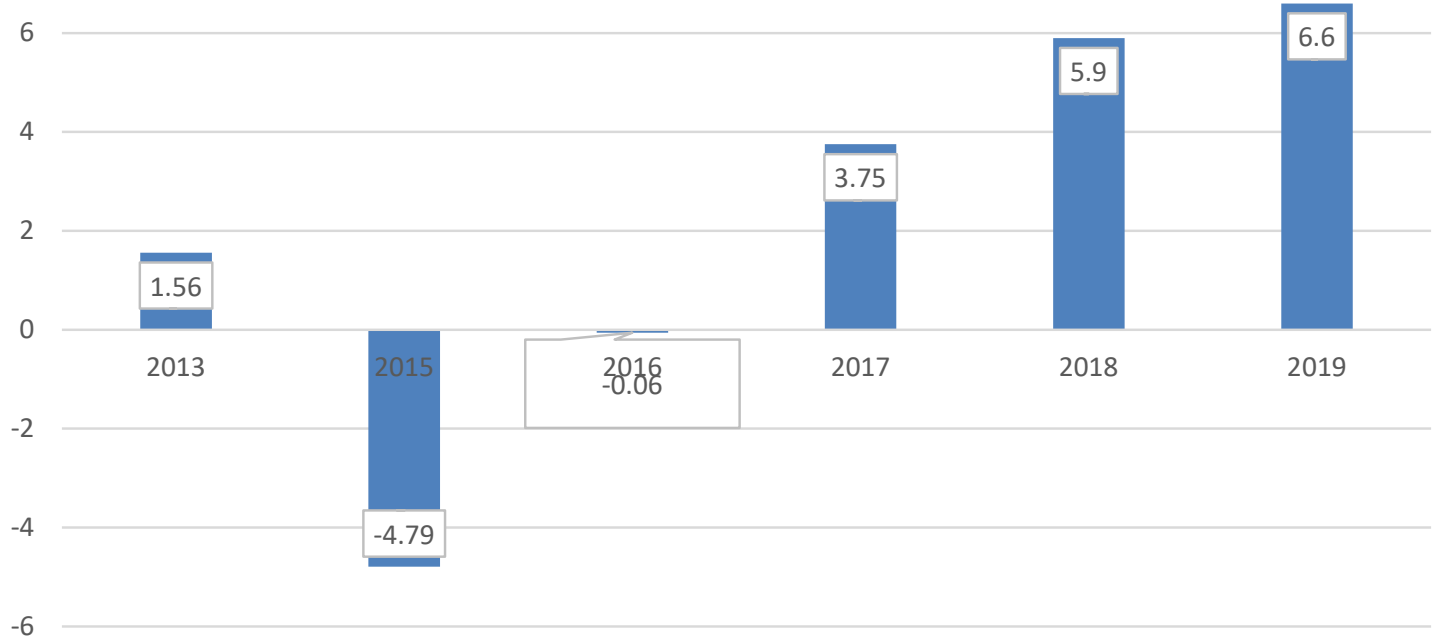

Fig. 1. Indonesian Textile Sector Exports

Therefore, the Indonesian sector of textile has significant growth in the market. That is the reason this sector is vital for the government of Indonesia. Because this sector has an important role in the economy of Indonesia. Economic development of Indonesia has a positive effect on the business performance as well as business sustainability. Growth of the Indonesian textile sector also shows the positive role in economic development. As this industry is quite important in various income generating cavities for the people which causes to increase the business performance (Salman et al., 2020). Therefore, the Indonesian textile industry has decent importance (Rohani et al., 2020). However, better sustainability in the business can be achieved with the help of sustainability among the operations. To achieve sustainability in business, a company always requires better sustainability in each area of the organization. While product development, it is required to achieve sustainability in all operations. For instance, while developing a product, it has many steps, in this direction each step must be sustainable with better performance. Therefore, sustainability in the operations is required (Gholami et al., 2020; Shou et al., 2019) to achieve higher sustainability in the overall operations of the company. In this regard, business sustainability in the textile sector is most important to achieve with the help of achieving sustainability in the business operations. Sustainability in the operations required sustainability in the innovation process. Innovation is the vital element of all organizations (Hameed et al., 2018; Razzaq et al., 2019). Innovation in the process is required for business sustainability. Moreover, innovation in production is also required among the textile companies to enhance business sustainability. Furthermore, innovation in supply chain activities is also key to gain sustainability in the business. However, to bring innovation in process, production and supply chain, it requires innovative ideas. Innovative ideas have the potential to lead innovation processes, innovation in production and innovation in supply chain. Therefore, the objective of the current study is to examine the role of innovative ideas in business sustainability. In this way, the relationship between innovative ideas, innovative process, innovative production, innovative supply chain and business sustainability was examined. Number of studies have examined the sustainability in the innovation (Bellucci et al., 2020; Manning et al., 2019; Ševkušić et al., 2020), however, the role of innovative ideas is not examined by the previous studies. Especially, the relationship discussed in the current study is not properly discussed in relation to the textile industry.

\section{Literature Review}

Innovation is based on the unique idea which is applied to enhance the performance of various organizational operations. The improvement in innovation has a major role on performance of the organization. Business always requires better ideas to improve the performance of business. Innovative is the application of ideas to improve the process, product or services at reduced cost (Hameed et al., 2018). Innovation is the new idea which has the potential to enhance the quality of the products, process or services at low cost. As cost is the major concern of organizations, that is the reason companies always try to reduce the cost by implementing better technology. Most of the customers always consider the price of the product while purchasing the product. Therefore, while applying new ideas for innovation, the cost is the major concern. Similarly, it is also important for the textile companies. In textile companies, the introduction of new ideas has major importance. Because innovation has a vital role in textile companies to foster the operations (de Oliveira Brasil et al., 2016; Gökmen \& Hamşioğlu, 2011). Therefore, this study is concerned with the investigation of innovative ideas to examine the effect on business sustainability. Moreover, this study also considered the role of innovative process, innovative production and innovative supply chain. Hence, the relationship between innovative ideas, innovative process, innovative production, innovative supply chain and business sustainability was examined as shown in Fig. 2. 


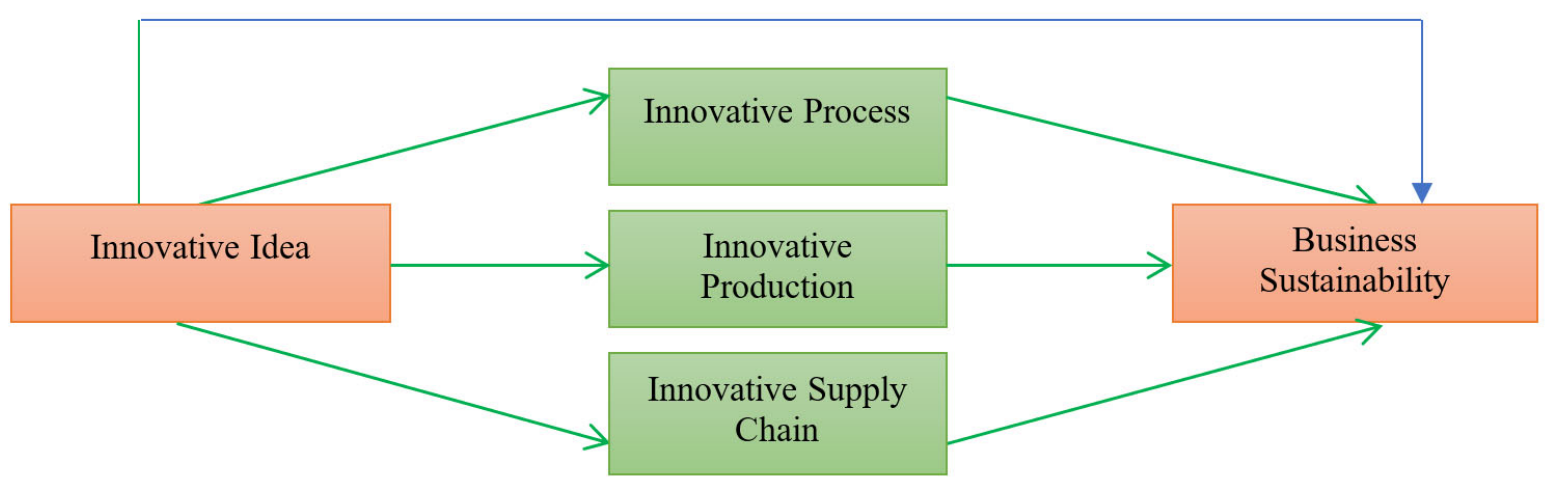

Fig. 2. Theoretical framework of the study showing the relationship between innovative idea, innovative process, innovative production, innovative supply chain and business sustainability

\subsection{Innovative Idea and Business Sustainability}

There are several operations that remain working for twenty-four hours to complete the process in textile companies. Manufacturing of clothes requires many steps. To deal with all these steps in a perfect way, innovative ideas are always required. Because each step has significant const which contribute to the overall process of the product. In this direction, introduction of new ideas to the process may decrease the overall cost. It also decreases the error which has the potential to increase the performance. In addition to this, innovative ideas also decrease the overall time to manufacture a product. Thus, all the advantages of innovative ideas such as low cost, better quality and less time led to the sustainability in the business. Sustainability means to be consistent in the performance. As in the higher competition of the textile industry, it is mandatory to enhance the increase in the level of consistency in the performance. A bit longer and consistent performance is required for the textile companies to enhance the performance. Survival of the business, particularly, the survival of the business in the textile companies is not easy. Because both the local and international market is quite tough in which higher performance is required in relation to the quality as well as quantity. Hence, innovation and business sustainability have important relationships which lead to the performance (Dentchev et al., 2016; Evans et al., 2017).

Hypothesis 1. Innovative ideas have a positive role in business sustainability.

\subsection{Innovative Idea, Innovative Process and Business Sustainability}

Innovative ideas lead to the innovative process among the organizations. Because according to the various scholars working in innovation management, the definition of innovation is related to something new in the product, process or services. For example, according to Hameed et al. (2018), process impalement is a major part of innovation along with the innovation in production and services. Hence, this direction shows the process innovation has a relationship with innovative idea management. The process of manufacturing clothes in the textile industry is one of the lengthy processes which requires significant cost as well as time, in this process application of innovation ideas has major influence. Innovative ideas and innovative processes have a relationship (Fu et al., 2019). Therefore, innovative idea performance is required to enhance the overall performance. Furthermore, innovative processes lead to higher sustainability in business. This shows that innovative ideas are required to increase the business sustainability. Thus, innovative ideas lead to the innovative process and innovative processes lead to business sustainability. An innovative process has a relationship with business sustainability (Fükő et al., 2020).

Hypothesis 2. Innovative ideas have a positive role in the innovative process.

Hypothesis 3. Innovative processes have a positive role in business sustainability.

\subsection{Innovative Idea, Innovative Production and Business Sustainability}

Innovative ideas are not only connected with the innovation process, but it also has a positive role in innovative production. In textile companies, the production is the major part of manufacturing products. Not only in textile companies, in all types of company's production is the major part to manufacture final products for customers. The production in textile companies required a better level of innovation. Increase in the innovative ideas increase the innovative production. Innovative ideas and innovative production have major relationships (Scaramellini et al., 2017). Furthermore, an increase in innovative ideas increases the business performance as the innovation has a positive role to foster the business performance (Fernando et al., 2019).

Hypothesis 4. Innovative ideas have a positive role in innovative production. 
Hypothesis 5. Innovative production has a positive role in business sustainability.

\subsection{Innovative Idea, Innovative Supply Chain and Business Sustainability}

Finally, it is evident from the literature that innovative ideas also have a relationship with the supply chain. In textile companies, supply chain has crucial importance to carry on all the operations. Better innovative ideas lead to better performance. As supply chain has major importance for the companies (Ul-Hameed, Mohammad, Shahar, Aljumah, \& Azizan, 2019) which lead to the business performance. Increase in the innovative supply chain through innovative ideas has a positive role to enhance business sustainability. As mentioned by Luthra, Kumar, Zavadskas, Mangla, and Garza-Reyes (2020) that supply chain and business sustainability has important connections which lead to business success. Furthermore, this study used the mediating role of innovative process, innovative production and innovative supply chain which is reflected in following hypothesis.

Hypothesis 6. Innovative ideas have a positive role in innovative supply chains.

Hypothesis 7. Innovative supply chains have a positive role in business sustainability.

Hypothesis 8. Innovative process mediates the relationship between innovative ideas and business sustainability.

Hypothesis 9. Innovative production mediates the relationship between innovative ideas and business sustainability.

Hypothesis 10. Innovative supply chain mediates the relationship between innovative ideas and business sustainability.

\section{Methodology}

Research design of the current study is cross-sectional because data were collected from one point of time and nature of the current study is also cross-sectional based (Lou et al., 2010). Hence, by using cross-sectional research design, the current study used a quantitative research approach. As quantitative research is better to test the study hypotheses. This study is based on hypothesis development and testing with the help of statistical tools; therefore, a quantitative research approach is suitable to achieve the objective of this study. The relationship between innovative ideas, innovative process, innovative production, innovative supply chain and business sustainability was examined by developing a research questionnaire. A research questionnaire with the help of scale items was designed for data collection. Questionnaires were used to collect primary data. Development of the scale was based on the five key variables: innovative ideas, innovative process, innovative production, innovative supply chain and business sustainability. Each variable was measured by using a specific number of scale items. This study could not develop the scale items for any of the variables. However, all the scale items were used from the previous studies to test the effect of innovative ideas on business sustainability. In the development of the questionnaire, this study chooses Likert scale because it is important for the collection of views and opinions of individual people. Finally, after the development of the questionnaire, the current study started the data collection by distributing the questionnaires. 300 questionnaires were used in the survey for data collection. As the Indonesian textile companies are under investigation in the current study. Data was collected from Indonesian textile company employees. 300 questionnaires were sent to the textile companies with the help of email. In this process of data collection, the current study used cluster sampling (Ul-Hameed, Mohammad, \& Shahar, 2018) which is suitable in the current nature of the study. After developing different clusters, this study used simple random sampling for questionnaire distribution (Kaur, Patil, Shirk, \& Taillie, 1996) among the textile companies of Indonesia. Finally, 170 questionnaires were returned by the current study.

\section{Research Findings}

Various statistical tools are available in the field of statistics for data analysis. From all the statistical tools, the current study used the most appropriate tool for data analysis. In this study Partial Least Square (PLS) is most suitable for data analysis which is used by several previous studies in the literature (Hair et al., 2012, 2013, 2014; Iqbal \& Hameed, 2020; U1-Hameed et al., 2018). However, before to apply the PLS for data analysis, the current study examined the missing value in the data (Aydin \& ŞENOĞLU, 2018). It is given in Table 1. None of the questionnaire has missing value. After the examination of missing value, this study further proceeded for the data analysis through Smart PLS 3.

In the next step of analysis, this study applied confirmatory factor analysis (CFA) with the help of PLS. In CFA, the factor loadings were examined. Fig. 3 shows that; innovative ideas were measured by using seven scale items. Innovative process was measured by using three scale items. Innovation production was measured by using three scale items. Innovative supply chain was measured by using three scale items. Finally, business sustainability was measured by using eight scale items. Hence, a total 24 scale items were used in the current study. It is found that all the scale items have factor loadings above 0.7 . However, only one item has factor loadings below 0.7 but above 0.6. Along with Figure 3, Table 2 also shows the factor loadings. 
Table 1

Data Statistics

\begin{tabular}{|c|c|c|c|c|c|c|c|c|c|}
\hline & No. & Missing & Mean & Median & Min & Max & SD & Kurtosis & Skewness \\
\hline II1 & 1 & 0 & 3.554 & 3 & 1 & 7 & 0.823 & 4.49 & 0.839 \\
\hline II 2 & 2 & 0 & 3.185 & 3 & 1 & 7 & 1.558 & -0.146 & 0.209 \\
\hline II3 & 3 & 0 & 3.631 & 4 & 1 & 7 & 1.565 & 0.015 & 0.195 \\
\hline II4 & 4 & 0 & 3.262 & 4 & 1 & 7 & 1.739 & -0.672 & 0.161 \\
\hline II5 & 5 & 0 & 3.477 & 4 & 1 & 7 & 1.29 & 0.844 & -0.08 \\
\hline II6 & 6 & 0 & 3.446 & 4 & 1 & 7 & 1.404 & 0.641 & 0.045 \\
\hline II7 & 7 & 0 & 3.385 & 4 & 1 & 7 & 1.536 & -0.123 & 0.027 \\
\hline IP1 & 8 & 0 & 3.769 & 4 & 1 & 7 & 1.476 & 0.396 & 0.117 \\
\hline IP2 & 9 & 0 & 3.708 & 4 & 1 & 7 & 1.725 & -0.446 & 0.173 \\
\hline IP3 & 10 & 0 & 3.554 & 4 & 1 & 7 & 1.436 & 0.942 & 0.48 \\
\hline IPRO1 & 11 & 0 & 3.523 & 4 & 1 & 7 & 1.589 & 0.001 & 0.263 \\
\hline IPRO2 & 12 & 0 & 3.677 & 4 & 1 & 7 & 1.337 & 0.998 & 0.381 \\
\hline IPRO3 & 13 & 0 & 3.554 & 4 & 1 & 7 & 1.579 & 0.054 & 0.199 \\
\hline ISC 1 & 14 & 0 & 3.431 & 4 & 1 & 7 & 1.312 & 0.626 & -0.013 \\
\hline ISC2 & 15 & 0 & 3.646 & 4 & 1 & 7 & 1.503 & 0.364 & 0.24 \\
\hline ISC3 & 16 & 0 & 3.462 & 4 & 1 & 7 & 1.618 & 0.026 & 0.171 \\
\hline BS1 & 17 & 0 & 3.569 & 4 & 1 & 7 & 1.539 & 0 & 0.061 \\
\hline BS2 & 18 & 0 & 2.954 & 3 & 1 & 5 & 1.115 & -0.629 & -0.111 \\
\hline BS3 & 19 & 0 & 2.969 & 3 & 1 & 5 & 1.022 & -0.064 & 0.328 \\
\hline BS4 & 20 & 0 & 3.092 & 3 & 1 & 5 & 0.94 & 0.15 & -0.189 \\
\hline BS5 & 21 & 0 & 3.2 & 3 & 1 & 5 & 0.98 & 0.499 & 0.084 \\
\hline BS6 & 22 & 0 & 3.246 & 3 & 1 & 5 & 0.842 & 0.359 & -0.343 \\
\hline BS7 & 23 & 0 & 3.046 & 3 & 1 & 5 & 0.919 & -0.125 & -0.337 \\
\hline BS8 & 24 & 0 & 3 & 3 & 1 & 5 & 0.977 & -0.037 & 0.304 \\
\hline
\end{tabular}

Table 2

Factor Loadings

\begin{tabular}{|c|c|c|c|c|c|}
\hline & Business Sustainability & Innovative Idea & Innovative Process & Innovative Production & Innovative Supply Chain \\
\hline BS1 & 0.686 & & & & \\
\hline $\mathrm{BS} 2$ & 0.857 & & & & \\
\hline BS3 & 0.847 & & & & \\
\hline BS4 & 0.795 & & & & \\
\hline BS5 & 0.83 & & & & \\
\hline BS6 & 0.792 & & & & \\
\hline BS7 & 0.781 & & & & \\
\hline BS8 & 0.869 & & & & \\
\hline II1 & & 0.854 & & & \\
\hline II 2 & & 0.904 & & & \\
\hline II 3 & & 0.853 & & & \\
\hline II4 & & 0.834 & & & \\
\hline II5 & & 0.859 & & & \\
\hline II6 & & 0.91 & & & \\
\hline II7 & & 0.892 & & & \\
\hline IP1 & & & 0.859 & & \\
\hline IP2 & & & 0.914 & & \\
\hline IP3 & & & 0.927 & & \\
\hline IPRO1 & & & & 0.885 & \\
\hline IPRO2 & & & & 0.869 & \\
\hline IPRO3 & & & & 0.947 & \\
\hline ISC1 & & & & & 0.856 \\
\hline ISC2 & & & & & 0.928 \\
\hline ISC3 & & & & & 0.929 \\
\hline
\end{tabular}

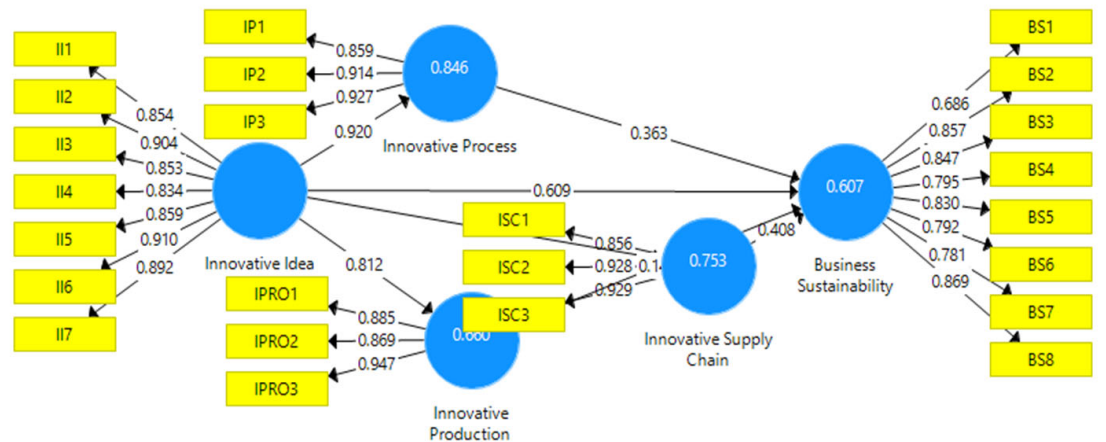

Fig. 3. Measurement Model 
In addition to the factor loadings, in the next step, the current study examined the composite reliability (CR) and average variance extracted (AVE). Discriminant validity was assessed through cross-loadings (Fornell \& Larcker, 1981) which is shown in Table 4. It is shown in Table 3 that all the variables; innovative ideas, innovative process, innovative production, innovative supply chain and business sustainability have CR above 0.7. Moreover, it is also shown in Table 3 that all the variables; innovative ideas, innovative process, innovative production, innovative supply chain and business sustainability have AVE above 0.7. Hair et al. (2017) recommended that all the variables should have CR above 0.7 and AVE above 0.5. $\mathrm{CR}$ and AVE above 0.7 and 0.5 respectively is the indication of the achievement of convergent validity.

Table 3

Reliability and Convergent Validity

\begin{tabular}{|c|c|c|c|c|}
\hline & Alpha & rho_A & $\mathbf{C R}$ & AVE \\
\hline Business Sustainability & 0.924 & $0.9 \overline{33}$ & 0.938 & 0.654 \\
\hline Innovative Idea & 0.948 & 0.948 & 0.957 & 0.762 \\
\hline Innovative Process & 0.883 & 0.884 & 0.928 & 0.811 \\
\hline Innovative Production & 0.884 & 0.888 & 0.928 & 0.812 \\
\hline Innovative Supply Chain & 0.889 & 0.891 & 0.931 & 0.819 \\
\hline
\end{tabular}

Table 4

Cross-Loadings

\begin{tabular}{|c|c|c|c|c|c|}
\hline & Business Sustainability & Innovative Idea & Innovative Process & Innovative Production & Innovative Supply Chain \\
\hline BS1 & 0.89 & 0.753 & 0.782 & 0.759 & 0.831 \\
\hline $\mathrm{BS} 2$ & 0.857 & 0.677 & 0.599 & 0.581 & 0.63 \\
\hline BS3 & 0.846 & 0.593 & 0.482 & 0.479 & 0.582 \\
\hline BS4 & 0.794 & 0.46 & 0.392 & 0.393 & 0.443 \\
\hline BS5 & 0.828 & 0.484 & 0.404 & 0.4 & 0.491 \\
\hline BS6 & 0.792 & 0.502 & 0.458 & 0.466 & 0.52 \\
\hline BS7 & 0.781 & 0.512 & 0.443 & 0.405 & 0.52 \\
\hline BS8 & 0.869 & 0.697 & 0.602 & 0.495 & 0.612 \\
\hline III & 0.686 & 0.854 & 0.765 & 0.717 & 0.7 \\
\hline II2 & 0.616 & 0.904 & 0.848 & 0.752 & 0.748 \\
\hline II3 & 0.645 & 0.853 & 0.815 & 0.722 & 0.754 \\
\hline II4 & 0.697 & 0.834 & 0.827 & 0.764 & 0.712 \\
\hline II5 & 0.673 & 0.859 & 0.751 & 0.661 & 0.835 \\
\hline II6 & 0.634 & 0.91 & 0.838 & 0.656 & 0.801 \\
\hline II7 & 0.631 & 0.892 & 0.771 & 0.688 & 0.748 \\
\hline IP1 & 0.522 & 0.819 & 0.866 & 0.727 & 0.687 \\
\hline IP2 & 0.703 & 0.849 & 0.909 & 0.801 & 0.856 \\
\hline IP3 & 0.594 & 0.816 & 0.926 & 0.852 & 0.752 \\
\hline IPRO1 & 0.587 & 0.773 & 0.875 & 0.888 & 0.754 \\
\hline IPRO2 & 0.55 & 0.677 & 0.693 & 0.867 & 0.618 \\
\hline IPRO3 & 0.598 & 0.74 & 0.802 & 0.947 & 0.736 \\
\hline ISC 1 & 0.67 & 0.739 & 0.767 & 0.801 & 0.856 \\
\hline ISC2 & 0.673 & 0.849 & 0.8 & 0.677 & 0.928 \\
\hline ISC3 & 0.678 & 0.764 & 0.742 & 0.654 & 0.929 \\
\hline
\end{tabular}

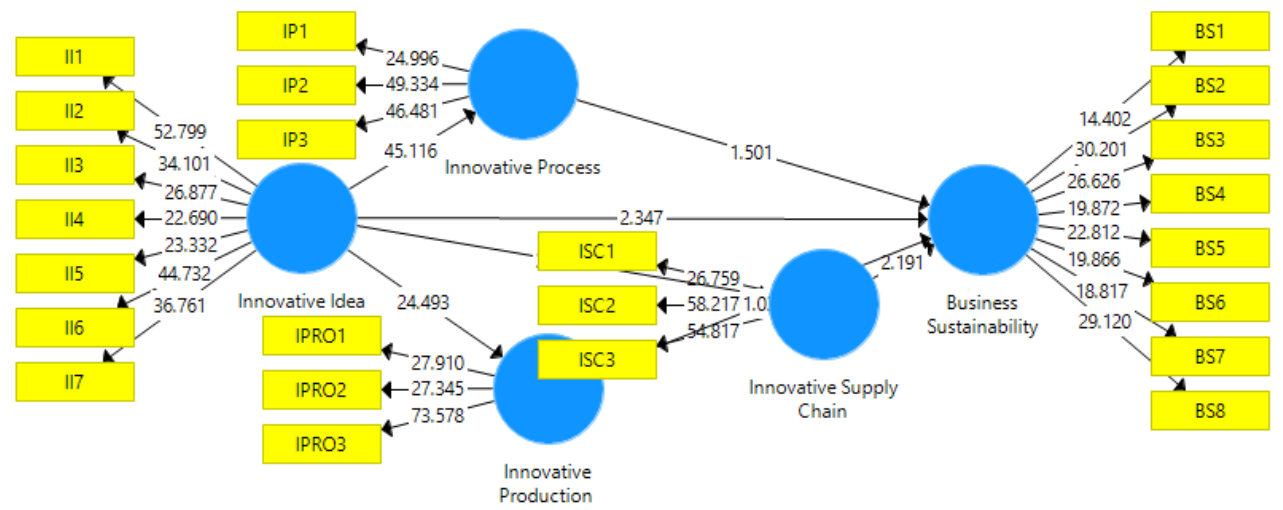

Fig. 4. Structural Model

Inner model of PLS is given in Fig. 4. According to this model, the direct effect of innovative ideas is examined in relation to business sustainability. The direct effect of innovative ideas is also examined on the innovative process. Along with this, the direct effect of innovative ideas was examined on innovative production and supply chain. Moreover, after the examination 
of the direct effect on innovative process, innovative production and innovative supply chain, the direct effect of innovative process, innovative production and innovative supply chain was examined on business sustainability. This process was examined with the help of PLS bootstrapping (Henseler \& Chin, 2010; Henseler \& Fassott, 2010; Henseler et al., 2009; Reinartz et al., 2009). Results of the study shows in Table 5 which indicates that innovative ideas have a positive effect on business sustainability. Innovative ideas also have a positive effect on innovative processes and innovation production. This innovative idea has a positive role in the innovative supply chain. Thus, innovative ideas have a positive effect on innovative processes, innovative production, and innovative supply chain. Hence, increase in innovative ideas increases the innovative process, innovative production, and innovative supply chain. Finally, an innovative supply chain shows a positive role in business sustainability. As an innovative supply chain has a positive effect on business sustainability. Furthermore, it is found that innovative processes and innovative production have no effect on business sustainability.

Table 5

Direct Effect Results

\begin{tabular}{|c|c|c|c|c|c|}
\hline & (O) & (M) & SD & T Statistics & P Values \\
\hline Innovative Idea $\rightarrow$ Business Sustainability & 0.609 & 0.617 & 0.26 & 2.347 & 0.019 \\
\hline Innovative Idea $\rightarrow$ Innovative Process & 0.92 & 0.921 & 0.02 & 45.116 & 0 \\
\hline Innovative Idea $\rightarrow$ Innovative Production & 0.812 & 0.817 & 0.033 & 24.493 & 0 \\
\hline Innovative Idea $\rightarrow$ Innovative Supply Chain & 0.868 & 0.867 & 0.026 & 32.834 & 0 \\
\hline Innovative Process $\rightarrow$ Business Sustainability & -0.363 & -0.357 & 0.242 & 1.501 & 0.134 \\
\hline Innovative Production $\rightarrow$ Business Sustainability & 0.145 & 0.142 & 0.141 & 1.03 & 0.303 \\
\hline Innovative Supply Chain $\rightarrow$ Business Sustainability & 0.408 & 0.399 & 0.186 & 2.191 & 0.029 \\
\hline
\end{tabular}

In Table 6, the mediation effect was examined. The mediation effect of the innovative process was examined between innovative ideas and business sustainability. The mediation effect of innovative production was examined between innovative ideas and business sustainability. Moreover, the third mediation effect of innovative supply chains was examined between innovative ideas and business sustainability. Results of the study shows that the mediation effect of innovative production between innovative ideas and business sustainability is not significant. The mediation effect of innovative production between innovative ideas and business sustainability is also not significant. The mediation effect of innovative supply chain between innovative idea and business sustainability is significant with t-value 2.206 . T-value is above 1.96 which shows that an innovative supply chain reflects the positive effect of innovative ideas on business sustainability. This mediation effect is also given in Figure 5. Finally, this study also examined the $\mathrm{r}$ square. This study has $0.607 \mathrm{r}$-square value for business sustainability. It shows that all the variables; innovative ideas, innovative process, innovative production and innovative supply chain are expected to bring $60.7 \%$ change in business sustainability. This r-square value showing the variance in business sustainability is moderate (Chin, 1998).

Table 6

Indirect Effect Results

\begin{tabular}{|c|c|c|c|c|c|}
\hline & (O) & (M) & SD & T Statistics & P Values \\
\hline Innovative Idea $\rightarrow$ Innovative Process $\rightarrow$ Business Sustainability & -0.334 & -0.328 & 0.223 & 1.494 & 0.136 \\
\hline Innovative Idea $\rightarrow$ Innovative Production $\rightarrow$ Business Sustainability & 0.118 & 0.117 & 0.116 & 1.013 & 0.312 \\
\hline Innovative Idea $\rightarrow$ Innovative Supply Chain $\rightarrow$ Business Sustainability & 0.354 & 0.345 & 0.161 & 2.206 & 0.028 \\
\hline
\end{tabular}

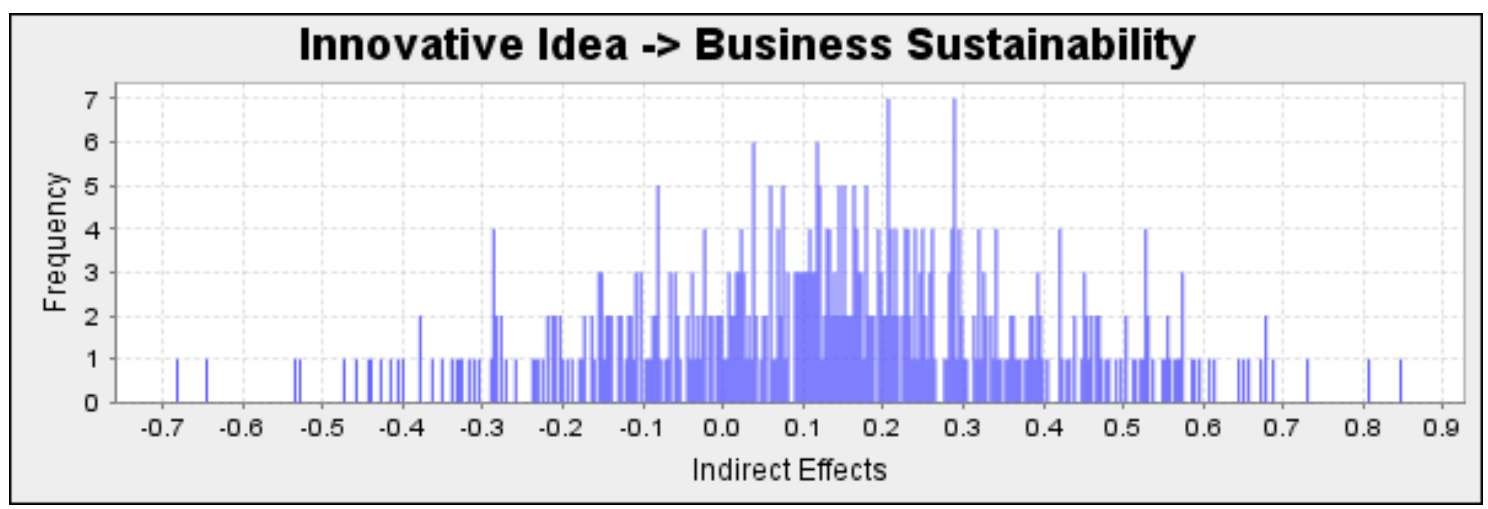

\section{Conclusion}

This study is an investigation related to innovative ideas and business sustainability. The objective of the current study was to examine the role of innovative ideas in business sustainability. For this purpose, the relationship between innovative ideas, innovative process, innovative production, innovative supply chain and business sustainability was examined. In addition to this, the mediating role of innovative process, innovative production and innovative supply chain was examined. To examine these relationships; data were collected from the employees of textile companies. Data were collected from Indonesian textile 
company employees in Indonesia. Results of the study found valuable insights for the textile companies. According to the results, innovation is the most influential element which causes increased business performance. Innovation leads to the sustainability of the business and provides better strength to the companies to compete in the market. The process of innovation generates various ideas which further lead to the business operations. Results of the study highlighted that innovative ideas have a major role in business sustainability. Majorly, the business sustainability depends on innovation which leads to novelty. Introduction of new ideas inside the boundaries of the organization expedites the business sustainability. As the business sustainability is key to the business, therefore, it requires innovative ideas for better performance. Furthermore, innovative ideas have a positive effect on innovative production and innovative supply chains. It is found that innovative ideas are one of the major parts of any organization including textile companies which shows a positive role to increase sustainable business. Along with this, improvement in the supply chain sustainability also shows a positive effect on business sustainability. Moreover, innovative production as well as innovative supply chain has a positive effect on business sustainability. Increase in innovative products and innovative supply chain increases the business sustainability. Therefore, innovative ideas increase the innovative production and innovative supply chain which further shows a positive effect on business sustainability. Hence, innovative ideas have a vital role in business sustainability among the Indonesian textile companies.

\section{Implications of the Study}

Several implications of the current study are based on the relationship between innovative ideas, innovative process, innovative production, innovative supply chain and business sustainability. This relationship among the textile companies along with the business sustainability was not previously discussed. Therefore, this is a vital addition in the literature of SMEs. It also contributed to the innovation. In rare cases, any study has highlighted the direct relationship between sustainable business and innovative ideas. The other theoretical implication of the current study is that; this study examined the threemediation effect. The first mediation effect of the innovative process was examined between innovative idea and business sustainability. The second mediation effect of innovative production was examined between innovative ideas and business sustainability. Finally, the third mediation effect of the innovative supply chain was examined between innovative ideas and business sustainability. Hence, the current study has several contributions to the body of literature. Practically, this study has valuable contributions for management of textile companies. As the current study suggested that innovative ideas should be enhanced by the textile companies to enhance the business sustainability. Textile companies can enhance the business by promoting innovative processes, innovative production and innovation supply chain.

\section{Limitations of the Study}

Apart from the valuable results for the practitioners, the current study has few limitations. The limitations in the current study could be the future directions. First, this study could not cover all the major aspects of innovation in relation to the textile companies. Therefore, other aspects of innovation are also important to handle business sustainability. For instance, Industry 4.0 is one of the most important innovative work in the current decade, therefore, various practices of Industry 4.0 should also be included in the current study model. Second, the current study results show the information availability has no effect on business sustainability. Generally, information from the market also has insights to handle the business performance. Therefore, future study should investigate why information availability has no effect on the business sustainability.

\section{References}

Aydin, D., \& Şenoğlu, B. (2018). Estimating the Missing Value in One-Way Anova Under Long-Tailed Symmetric Error Distributions. Sigma: Journal Of Engineering \& Natural Sciences/Mühendislik Ve Fen Bilimleri Dergisi, 36(2).

Bellucci, M., Bini, L., \& Giunta, F. (2020). Implementing Environmental Sustainability Engagement Into Business: Sustainability Management, Innovation, And Sustainable Business Models Innovation Strategies In Environmental Science (Pp. 107-143): Elsevier.

Chin, W. W. (1998). The Partial Least Squares Approach To Structural Equation Modeling. Modern Methods For Business Research, 295(2), 295-336.

De Oliveira Brasil, M. V., De Abreu, M. C. S., Da Silva Filho, J. C. L., \& Leocádio, A. L. (2016). Relationship Between EcoInnovations And The Impact On Business Performance: An Empirical Survey Research On The Brazilian Textile Industry. Revista De Administração, 51(3), 276-287.

Dentchev, N., Baumgartner, R., Dieleman, H., Jóhannsdóttir, L., Jonker, J., Nyberg, T., . . Tang, X. (2016). Embracing the Variety of Sustainable Business Models: Social Entrepreneurship, Corporate Intrapreneurship, Creativity, Innovation, and Other Approaches to Sustainability Challenges. Journal Of Cleaner Production.

Evans, S., Vladimirova, D., Holgado, M., Van Fossen, K., Yang, M., Silva, E. A., \& Barlow, C. Y. (2017). Business Model Innovation For Sustainability: Towards A Unified Perspective For Creation Of Sustainable Business Models. Business Strategy and the Environment, 26(5), 597-608.

F. Hair Jr, J., Sarstedt, M., Hopkins, L., \& G. Kuppelwieser, V. (2014). Partial Least Squares Structural Equation Modeling (PLS-SEM) An Emerging Tool in Business Research. European Business Review, 26(2), 106-121. 
Fernando, Y., Jabbour, C. J. C., \& Wah, W.-X. (2019). Pursuing Green Growth In Technology Firms Through The Connections Between Environmental Innovation And Sustainable Business Performance: Does Service Capability Matter? Resources, Conservation And Recycling, 141, 8-20.

Fornell, C., \& Larcker, D. F. (1981). Structural Equation Models With Unobservable Variables And Measurement Error: Algebra And Statistics. Journal Of Marketing Research, 382-388.

Fu, S., Cheng, X., De Vreede, T., De Vreede, G.-J., Seeber, I., Maier, R., \& Weber, B. (2019). Exploring Idea Convergence And Conceptual Combination In Open Innovative Crowdsourcing From A Cognitive Load Perspective. Paper Presented at the Proceedings of the $52^{\text {nd }}$ Hawaii International Conference on System Sciences.

Fükő, L., Illés, B., Skapinyecz, R., Hardai, I., Tóth, Á. B., Bányai, T., . . . Tamás, P. (2020). Increasing the Sustainability of Forklift Material Handling Systems By Using an Innovative Process Development Method. Academic Journal of Manufacturing Engineering, 18(2).

Gholami, H., Bachok, M. F., Saman, M. Z. M., Streimikiene, D., Sharif, S., \& Zakuan, N. (2020). An ISM Approach For The Barrier Analysis In Implementing Green Campus Operations: Towards Higher Education Sustainability. Sustainability, 12(1), 363.

Gökmen, A., \& Hamşioğlu, A. B. (2011). The Effect Of Knowledge Management, Technological Capability And Innovation On The Enterprise Performance: A Comprehensive Emperical Study Of The Turkish Textile Sector. Journal Of Information \& Knowledge Management, 10(01), 1-10.

Hair, J., Hollingsworth, C. L., Randolph, A. B., \& Chong, A. Y. L. (2017). An Updated And Expanded Assessment Of PLSSEM In Information Systems Research. Industrial Management \& Data Systems, 117(3), 442-458.

Hair, J. F., Ringle, C. M., \& Sarstedt, M. (2013). Partial Least Squares Structural Equation Modeling: Rigorous Applications, Better Results And Higher Acceptance.

Hair, J. F., Sarstedt, M., Pieper, T. M., \& Ringle, C. M. (2012). The Use Of Partial Least Squares Structural Equation Modeling In Strategic Management Research: A Review Of Past Practices And Recommendations For Future Applications. Long Range Planning, 45(5-6), 320-340.

Hameed, W. U., Basheer, M. F., Iqbal, J., Anwar, A., \& Ahmad, H. K. (2018). Determinants Of Firm's Open Innovation Performance And The Role Of R \& D Department: An Empirical Evidence From Malaysian SME's. Journal Of Global Entrepreneurship Research, 8(1), 29.

Henseler, J., \& Chin, W. W. (2010). A Comparison Of Approaches For The Analysis Of Interaction Effects Between Latent Variables Using Partial Least Squares Path Modeling. Structural Equation Modeling, 17(1), 82-109.

Henseler, J., \& Fassott, G. (2010). Testing Moderating Effects In PLS Path Models: An Illustration Of Available Procedures Handbook Of Partial Least Squares (Pp. 713-735): Springer.

Henseler, J., Ringle, C. M., \& Sinkovics, R. R. (2009). The Use Of Partial Least Squares Path Modeling In International Marketing New Challenges To International Marketing (Pp. 277-319): Emerald Group Publishing Limited.

Iqbal, J., \& Hameed, W. U. (2020). Open Innovation Challenges And Coopetition-Based Open-Innovation Empirical Evidence From Malaysia Innovative Management And Business Practices In Asia (Pp. 144-166): IGI Global.

Jermsittiparsert, K. (2020). Leadership And Industry 4.0 As A Tool To Enhance Organization Performance: Direct And Indirect Role Of Job Satisfaction, Competitive Advantage And Business Sustainability. In B. Akkaya (Ed.), Agile Business Leadership Methods For Industry 4.0 (Pp. 233-257). West Yorkshire: Emerald Publishing Limited.

Jermsittiparsert, K. (2021). Green Intellectual Capital Factors Leading To Business Sustainability. E3S Web Of Conferences, 277, 06009.

Kaur, A., Patil, G., Shirk, S. J., \& Taillie, C. (1996). Environmental Sampling With A Concomitant Variable: A Comparison Between Ranked Set Sampling And Stratified Simple Random Sampling. Journal Of Applied Statistics, 23(2-3), 231-256.

Lou, J.-H., Chen, S.-H., Yu, H.-Y., Li, R.-H., Yang, C.-I., \& Eng, C.-J. (2010). The Influence Of Personality Traits And Social Support On Male Nursing Student Life Stress: A Cross-Sectional Research Design. Journal Of Nursing Research, 18(2), 108-116.

Luthra, S., Kumar, A., Zavadskas, E. K., Mangla, S. K., \& Garza-Reyes, J. A. (2020). Industry 4.0 As An Enabler Of Sustainability Diffusion In Supply Chain: An Analysis Of Influential Strength Of Drivers In An Emerging Economy. International Journal Of Production Research, 58(5), 1505-1521.

Manning, B., Braam, G., \& Reimsbach, D. (2019). Corporate Governance And Sustainable Business Conduct-E Ffects Of Board Monitoring Effectiveness And Stakeholder Engagement On Corporate Sustainability Performance And Disclosure Choices. Corporate Social Responsibility And Environmental Management, 26(2), 351-366.

Razzaq, S., Maqbool, N., \& Hameed, W. U. (2019). Factors Effecting The Elasticity Of Micro Credit Demand In Southern Punjab, Pakistan. International Journal Of Social Sciences And Economic Review, 1(2), 46-53.

Reinartz, W., Haenlein, M., \& Henseler, J. (2009). An Empirical Comparison Of The Efficacy Of Covariance-Based And Variance-Based SEM. International Journal Of Research In Marketing, 26(4), 332-344.

Rohani, S., Siregar, A., Rasyid, T., Aminawar, M., \& Darwis, M. (2020). The Farmer Competency That Doing Partnership Systems (Teseng) In Beef Cattle Business At Bone Regency, South Sulawesi Province, Indonesia. Paper Presented At The IOP Conference Series: Earth And Environmental Science

Rossi, E., Bertassini, A. C., Dos Santos Ferreira, C., Do Amaral, W. A. N., \& Ometto, A. R. (2020). Circular Economy Indicators For Organizations Considering Sustainability And Business Models: Plastic, Textile And Electro-Electronic Cases. Journal Of Cleaner Production, 247, 119137. 
Salman, A. A., Rahman, A. A., Sitorus, M. B., Wok, R., Mustapha, S. M., \& Ghani, N. A. A. (2020). The The Impact of Knowledge and Skills Acquired on Business Performance of Malaysia and Indonesia TVET Graduates. International Journal of Technical Vocational and Engineering Technology, 2(1), 1-14.

Scaramellini, S., Cerri, P., Bianco, A., \& Masi, S. (2017). Energy Efficiency Boosting: Field Application of an Innovative Integrated Production Optimization Tool To Maximize Production and Save Energy. Paper presented at the Offshore Mediterranean Conference and Exhibition

Ševkušić, M., Kosanović, B., \& Šipka, P. (2020). Serbian Citation Index: The sustainability of a business model based on partnership between a non-profit web publisher and journal owners. Paper presented at the ELPUB 2020 24rd edition of the International Conference on Electronic Publishing

Shou, Y., Shao, J., Lai, K.-h., Kang, M., \& Park, Y. (2019). The impact of sustainability and operations orientations on sustainable supply management and the triple bottom line. Journal of Cleaner Production, 240, 118280.

Ul-Hameed, W., Mohammad, H., \& Shahar, H. (2018). Microfinance institute's non-financial services and womenempowerment: The role of vulnerability. Management Science Letters, 8(10), 1103-1116.

Ul-Hameed, W., Mohammad, H., Shahar, H., Aljumah, A., \& Azizan, S. (2019). The effect of integration between audit and leadership on supply chain performance: Evidence from UK based supply chain companies. Uncertain Supply Chain Management, 7(2), 311-328.

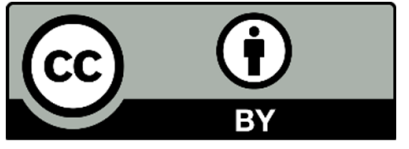

(C) 2022 by the authors; licensee Growing Science, Canada. This is an open access article distributed under the terms and conditions of the Creative Commons Attribution (CCBY) license (http://creativecommons.org/licenses/by/4.0/). 